\title{
Overexpression of Brain-Derived Neurotrophic Factor Enhances Sensory Innervation and Selectively Increases Neuron Number
}

\author{
Ann M. LeMaster, ${ }^{1}$ Robin F. Krimm, ${ }^{2}$ Brian M. Davis, ${ }^{1}$ Teresa Noel, ${ }^{2}$ Mary E. Forbes, ${ }^{3}$ James E. Johnson, ${ }^{3}$ and \\ Kathryn M. Albers ${ }^{1,2}$

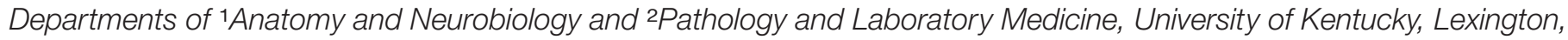 \\ Kentucky 40536, and ${ }^{3}$ Department of Neurobiology and Anatomy, Wake Forest University, Winston Salem, \\ North Carolina 27157
}

\begin{abstract}
Target-derived neurotrophin growth factors have significant effects on the development and maintenance of the mammalian somatosensory system. Studies of transgenic mice that overexpress neurotrophins NGF and neurotrophin 3 (NT-3) at high levels in skin have shown increased sensory neuron number and enhanced innervation of specific sensory ending types. The effects of two other members of this family, BDNF and NT-4, on sensory neuron development are less clear. This study examined the role of brain-derived neurotrophic factor (BDNF) using transgenic mice that overexpress BDNF in epithelial target tissues of sensory neurons. BDNF transgenic mice had an increase in peripheral innervation density and showed selective effects on neuron survival. Neuron number in trigeminal ganglia, DRG, and SCG were unchanged, although a $38 \%$ increase in neurons comprising the placode-derived nodose-petrosal complex occurred. BDNF transgenic skin showed notable en-
\end{abstract}

hancement of innervation to hair follicles as detected by PGP9.5 immunolabeling. In nonhairy plantar skin, Meissner corpuscle sensory endings were larger, and the number of Merkel cells with associated innervation was increased. In trigeminal ganglia, neurons expressing trkB receptor were increased threefold, whereas trkA-positive neurons doubled. Analysis of trkB by Northern, reverse transcription-PCR, and Western assays indicated a modest increase in the expression of the T1 truncated receptor and preferential distribution to the periphery. These data indicate that skin-derived BDNF does not enhance survival of cutaneous sensory neurons, although it does promote neurite innervation of specific sites and sensory end organs of the skin.

Key words: BDNF; transgenic; sensory; neurotrophin; Meissner; trkB
In vivo and in vitro studies have identified neurotrophin growth factors (NGF, NT-3, BDNF, and NT-4) as compounds essential for sensory neuron survival, sensory end organ development, and as modulators of adult sensory physiology (Buchman and Davies, 1993; Snider, 1994; Reichardt and Farinas, 1997; Carroll et al., 1998). During development, neurotrophin synthesis occurs in peripheral targets of developing sensory neurons, such as the skin (Davies et al., 1987). The neurotrophic hypothesis predicts that the level of neurotrophin regulates the onset and degree of neuron death that occurs during development and thereby sculpts the pattern and density of axon projections to specific targets in the periphery (Oppenheim, 1991). Indeed, mice that lack NGF or its high-affinity receptor trkA lose $70-80 \%$ of their cranial and spinal sensory neurons (Crowley et al., 1994), many of which are nociceptors. NT-3-deficient mice lose 55-65\% of sensory neurons, specifically lacking proprioceptive neurons and cutaneous neurons that innervate hair follicles and Merkel cells of touch dome mechanoreceptors (Airaksinen et al., 1996). Mice lacking BDNF have greatest deficits in sensory neurons of the nodosepetrosal ganglion (NPG) complex (39-66\% loss) and vestibular ganglia ( $82 \%$ loss), although they also lose $21-44 \%$ of trigeminal

\footnotetext{
Received Aug. 19, 1998; revised May 5, 1999; accepted May 6, 1999.

This work was supported by National Institutes of Health Grants NS33730 (K.M.A) and NS31826 (B.M.D). We thank James Simpson, Marc Jones, Mary Gail Engle, and Cynthia Long for excellent technical assistance.

Correspondence should be addressed to Kathryn M. Albers, University of Kentucky Medical Center, Department of Pathology and Laboratory Medicine, Suite MS 117, Lexington, KY 40536-0084.

Copyright (C) 1999 Society for Neuroscience 0270-6474/99/195919-13\$05.00/0
}

and 30-36\% of L4 dorsal root ganglia (DRG) neurons (Ernfors et al., 1994; Jones et al., 1994; Erickson et al., 1996). The identity of the types of sensory neurons lost from trigeminal and DRG in BDNF knock-out mice have not as yet been defined.

To investigate the requirement of target-derived neurotrophin synthesis in sensory neuron development and differentiation, we isolated transgenic mouse lines that overexpress each neurotrophin in the skin, a major target of sensory and sympathetic neurons that normally synthesizes neurotrophins. In line with the neurotrophic hypothesis, we anticipated that increased neurotrophins in the peripheral tissue should increase the survival of specific types of sensory neuron populations. This was indeed the case in mice that overexpressed NGF in which a doubling of sensory neuron number and significant increase in myelinated and unmyelinated fibers in the skin was found (Albers et al., 1994; Davis et al., 1997). In addition, a doubling in the percentage of neurons expressing trkA, the high-affinity receptor for NGF, also was found, indicating specific rescue of the NGF-dependent cell population (Goodness et al., 1997). Analysis of transgenic mice that overexpressed NT-3 also showed enhanced peripheral innervation, with specific enhancement of mechanoreceptive neurons associated with Merkel cells comprising touch dome sensory units of the skin (Albers et al., 1996). NT-3 transgenics also had increased sensory neuron numbers $(65-70 \%)$ and twice the number of trkC-positive neurons, indicating a significant role of target-derived NT-3 in neuron survival and differentiation.

BDNF neurotrophin is also expressed by the skin during development [beginning at approximately embryonic day 11 (E11)] 
(Buchman and Davies, 1993), although its role as a target-derived factor that supports neuron survival is less clear (Acheson and Lindsay, 1996). It may function instead in a paracrine or autocrine manner to regulate neuron survival and/or maturation (Wright et al., 1992; Robinson et al., 1996), because both BDNF and its high-affinity receptor trkB are expressed in neurons of developing sensory ganglia (Ernfors et al., 1990; Klein et al., 1990b; Schecterson and Bothwell, 1992). In addition, little if any information is known about the types of cutaneous sensory endings that are supported by BDNF expression in the skin. To address these issues and to test the role of BDNF as a targetderived survival factor, we established lines of transgenic mice that overexpressed BDNF in the epidermis, similar to our NGF and NT-3 lines. Our analysis indicates that, although BDNF did selectively increase innervation to the skin, it did not increase neuron number in the trigeminal or dorsal root ganglia. Although neuron number was unchanged in trigeminal and DRG populations, the number of neurons in the placode-derived nodosepetrosal sensory complex was increased, indicating a selective survival action of BDNF on neuronal types. Thus, we find that, similar to NGF and NT-3, BDNF altered somatosensory innervation patterns, but unlike NGF and NT-3, BDNF did not act as a target-derived survival factor for cranial or spinal sensory neurons.

\section{MATERIALS AND METHODS}

\section{Isolation of K14-BDNF transgenic mice}

Human K14 keratin promoter and enhancer sequences (2.5 kbp) were used to drive expression of a mouse BDNF cDNA isolated by PCR amplification of genomic DNA using primers $5^{\prime}$ ccagcgggatccgtgatgaccatcctttccttact $3^{\prime}$ and 5'cggtacggatcccataaatccactactttccct3'. Gene sequences encoding amino acids -131 to +124 (Yancopoulos et al., 1990) were amplified using primer sequences containing a BamHI site to facilitate cloning into the K14-hGH cassette (Vassar and Fuchs, 1991). The 770 bp PCR product was cloned into pGem4Z (Promega, Madison, WI) and sequenced to verify it encoded the BDNF peptide. The K14BDNF transgene was gel- and column-purified, microinjected into pronuclei of embryos obtained from B6 $\times$ C $3 \mathrm{H}$ F1 hybrid females (Harlan Sprague Dawley, Indianapolis, IN), and implanted into pseudopregnant females as described previously (Albers et al., 1994). Animals in this study were used in accordance with the guidelines of the U.S. Public Health Service Policy on Humane Care and Use of Laboratory Animals and the NIH Guide for the Care and Use of Laboratory Animals.

\section{Southern hybridization analysis}

Founder and F1 generations were analyzed by Southern blotting to identify transgenic lines and to verify transgene integration. Subsequent generations were screened by slot blot analysis of isolated tail DNA. Copy numbers were estimated by applying $2 \mu \mathrm{g}$ of genomic DNA to Nytran membranes, hybridizing with a ${ }^{32} \mathrm{P}$-labeled probe to the BDNF sequence, exposing membranes to photographic film, and using the NIH Image 1.57 software to measure relative band intensity.

\section{Histology and immunocytochemistry}

Age-matched mice were deeply anesthetized with $2.5 \%$ avertin $(2,2,2-$ tribromoethanol and tert-amyl alcohol diluted in $0.9 \%$ saline) and perfused with $4 \%$ paraformaldehyde in $0.1 \mathrm{~m}$ phosphate buffer. For hematoxylin-eosin staining, skin was post-fixed in $4 \%$ paraformaldehyde and $70 \%$ ethanol, embedded in paraffin, sectioned, and stained. For immunocytochemistry, mice were perfused with $4 \%$ paraformaldehyde, and tissues were post-fixed in $4 \%$ paraformaldehyde solution for $<2 \mathrm{hr}$, sunk in $25 \%$ sucrose $-0.1 \mathrm{~m}$ phosphate buffer, and embedded in $10 \%$ gelatin in $1 \times$ Tris-buffered saline. Tissue was cut at 20 - to $30-\mu \mathrm{m}$-thick sections, and sections were washed, blocked $1 \mathrm{hr}$ at room temperature in 5\% normal goat serum (NGS), $2 \%$ bovine serum albumin (BSA), and $0.25 \%$ Triton X-100, and incubated overnight in primary antibodies diluted in $5 \%$ NGS and $0.25 \%$ Triton solution. Sections were washed, incubated with 1:500 dilution of goat anti-rabbit biotinylated antibody (Vector Laboratories, Burlingame, CA) for $1 \mathrm{hr}$, washed, and treated with anti- endogenous peroxidase solution containing $2.5 \% \mathrm{H}_{2} \mathrm{O}_{2}$ and $5 \%$ methanol. For antibody detection, tissues were incubated in an avidin-biotincomplex mix (ABC, Vectastain Elite; Vector Laboratories) for $1 \mathrm{hr}$, washed, incubated in nickel enhanced- $0.04 \%$ diaminobenzene solution, and mounted onto Superfrost Plus slides (Lab Craft, Chelmsford, UK). A rabbit polyclonal antibody to PGP9.5 (an ubiquitin carboxyl terminal hydrolase that detects nearly all myelinated and unmyelinated nerve fibers) was used at 1:5000 (Ultraclone, Isle of Wight, UK). For K20 labeling, foot pad skin was first separated into epidermal and dermal compartments by incubating in $2 \mathrm{M}$ sodium bromide for $1 \mathrm{hr}$ at $37^{\circ} \mathrm{C}$. The epidermis was fixed in $-20^{\circ} \mathrm{C}$ acetone, incubated overnight in anti-K20 (1:10; Boehringer Mannheim, Indianapolis, IN) and anti-NF150 (Chemicon, Temecula, CA), washed, incubated in goat anti-mouse labeled $\mathrm{Cy} 3$ and goat anti-rabbit $\mathrm{Cy} 2$ antibody for $1 \mathrm{hr}$, washed, coverslipped in anti-fade solution, and viewed using a Leica (Nussloch, Germany) confocal microscope.

\section{BDNF peptide measures}

Electrochemiluminescence immunoassay. An electrochemiluminescence immunoassay (ECLIA) was one of two methods used to measure BDNF peptide. Tissue was homogenized in $50 \mathrm{vol}$ of $100 \mathrm{~mm}$ PIPES buffer, $\mathrm{pH}$ 7.0, containing $500 \mathrm{~mm} \mathrm{NaCl}, 2 \% \mathrm{BSA}, 0.2 \%$ Triton $\mathrm{X}-100,0.1 \% \mathrm{NaN}_{3}$, $2 \mu \mathrm{g} / \mathrm{ml}$ aprotinin, $2 \mathrm{~mm}$ EDTA, $10 \mu \mathrm{M}$ leupeptin, $1 \mu \mathrm{M}$ pepstatin, and $200 \mu \mathrm{M}$ phenylmethanesulfonyl fluoride using ground glass dounces. Samples were centrifuged at $16,000 \times g$ for $20 \mathrm{~min}$, supernatants were collected, and $53 \mu \mathrm{l}$ of $1 \mathrm{~N} \mathrm{NaOH}$ per milliliter of supernatant was added. The ECLIA reaction mixture contained $166 \mathrm{ng} / \mathrm{ml}$ biotinylated BDNF antibody (Amgen, Thousand Oaks, CA), $333 \mathrm{ng} / \mathrm{ml}$ ruthenium II tris (bipyridyl) $\left[\mathrm{Ru}(\right.$ bpy $) 3^{2+}$-labeled (TAG-labeled) BDNF antibody and 22 $\mu \mathrm{g} / \mathrm{ml}$ streptaviden magnetic beads diluted in calcium- and magnesiumfree Dulbecco's PBS, pH 7.2, containing 3\% BSA, $1.5 \%$ Tween 20, and $0.05 \% \mathrm{NaN}_{3}$. This mix $(150 \mu \mathrm{l})$ was added to $50 \mu \mathrm{l}$ of tissue supernatant in $12 \times 75 \mathrm{~mm}$ polypropylene tubes and vortexed for $90 \mathrm{~min}$ in an Origen Analyzer (IGEN International, Gaithersburg, MD) carousel, after which $200 \mu \mathrm{l}$ of Origen Assay (IGEN International) stop buffer was added. To biotinylate the BDNF antibody, $0.25 \mathrm{mg}$ of antibody in PBS was diluted with biotin-LC-sulfo-NHS ester to a molar ratio of 10:1 biotin/antibody protein. This mix was incubated $1 \mathrm{hr}$ at room temperature, terminated by adding $20 \mu \mathrm{l}$ of $2 \mathrm{M}$ glycine, passed through a PD-10 Sephadex column, and eluted with $150 \mathrm{~mm}$ potassium phosphate buffer, $\mathrm{pH}$ 7.2, containing $150 \mathrm{~mm} \mathrm{NaCl}$ and $0.05 \% \mathrm{NaN}_{3}$ preservative to remove unreacted biotinLC-sulfo-NHS ester. Biotin-labeled antibody fractions were identified using a micro BCA protein assay, pooled, stabilized by addition of $3 \%$ BSA, and stored at $4^{\circ} \mathrm{C}$. For TAG labeling, $0.25 \mathrm{mg}$ of anti-BDNF antibody was diluted with $\mathrm{Ru}[\mathrm{bpy}] 3^{2+}$-NHS ester dissolved in dimethylsulfoxide to achieve a final molar ratio of 7:1. The reaction mixture was incubated for $1 \mathrm{hr}$ at room temperature in the dark, followed by addition of $20 \mu \mathrm{l}$ of $2 \mathrm{M}$ glycine. The TAG-labeled mixture was passed through a PD-10 Sephadex column and eluted with $150 \mathrm{~mm}$ potassium phosphate buffer, $\mathrm{pH} 7.2$, containing $150 \mathrm{~mm} \mathrm{NaCl}$ and $0.05 \% \mathrm{NaN}_{3}$. TAG-labeled antibody fractions were identified by protein assay, pooled, stabilized by addition of $3 \% \mathrm{BSA}$, and stored at $4^{\circ} \mathrm{C}$.

ELISA. In later stages of this study, BDNF was assayed using a simpler, commercially available ELISA kit. Tissues were removed, weighed, and frozen until homogenized in sample buffer ( $0.1 \mathrm{M}$ PBS, 0.4 M NaCl, $0.1 \%$ Triton X-100, 2 mm EDTA, 0.1 mm benzethonium chloride, $2 \mathrm{~mm}$ benzamidine, $0.1 \mathrm{~mm}$ PMSF, 20 trypsan inhibitor unit $/ \mathrm{ml}$ aprotinin, and $0.5 \%$ BSA, $\mathrm{pH}$ 7.4) using either a polytron or Duall type ground glass homogenizer. Samples were spun at 13,000 rpm for $15 \mathrm{~min}$ at $4^{\circ} \mathrm{C}$, and supernatants were assayed using the BDNF $\mathrm{E}_{\max }$ ImmunoAssay system (Promega). Dynatech immulon plates were coated with an anti-BDNF monoclonal antibody to bind soluble BDNF from solution. Bound BDNF complexes were exposed to an anti-human BDNF polyclonal antibody, and the amount of bound antibody was detected using an anti-IgY antibody conjugated to horseradish peroxidase. Unbound conjugate was removed by washing, and the chromogenic substrate $3,3^{\prime}, 5,5^{\prime}-$ tetramethyl benzidine (TMB) was added. Bound BDNF was detected by catalyzed color development of TMB using a plate reader.

\section{Neuronal cell counting methodology}

Two counting methods were used to estimate the number of neurons in peripheral ganglia. Nodose, DRG, SCG, and trigeminal ganglia neurons were counted used a modified Abercrombie counting method as described previously (Davis et al., 1996). Briefly, ganglia were serial sectioned at $5 \mu \mathrm{m}$ and stained with cresyl violet, and the number of neurons 
containing nucleoli were counted. Nucleolar number was summed and multiplied by the interval between counted sections, and a correction factor for multiple or split nucleoli was applied. The number of trigeminal neurons was also estimated using the optical dissector method (West, 1993). Ganglia were isolated from mice perfused with $4 \%$ paraformaldehyde- $-0.1 \mathrm{M}$ phosphate buffer. Tissue was dehydrated through alcohols, embedded in graded celloidin (Mallinckrodt, Phillipsburg, NJ) through 50:50 ethanol/ether solutions, cut into $50 \mu \mathrm{m}$ sections, and stained with Giemsa. The area of sections containing neurons was outlined using a $2 \times$ objective to determine grid position. The $x$-axis of the grid was set at 30 $\mu \mathrm{m}$, and the $y$-axis was set at $60 \mu \mathrm{m}$ to increase the number of neurons sampled. Counting was done at every fifth intersection of the $x$ - and $y$-axes. The dimensions of the counting box were set large enough to fit one neuron $(x, 30 \mu \mathrm{m} ; y, 30 \mu \mathrm{m})$. Thus, the area sampling fraction (asf) is the area of the counting box $(x \times y)$ relative to the area where the counting occurred $[(5 \times x)(5 \times y)]$. Because section thickness $(t)$ was 50 $\mu \mathrm{m}$, the height of the counting box $(h)$ was set at $30 \mu \mathrm{m}$ to avoid small neuronal fragments. Using a $60 \times$ objective, neurons that appeared in the counting box or crossed the top, right, and back sides of the box were recorded, and neurons counted in each section summed $(Q)$. Neuronal number $(n)$ was determined by the equation $n=Q \times 1 / \mathrm{ssf} \times 1 /$ asf $\times t / h$. Because every section was counted, the ssf (section sampling frequency, i.e., number of sections counted per total number of sections) was not calculated. All analyses were done on age-matched mice processed in parallel.

\section{Electron microscopy}

Mice were perfused with $0.9 \%$ saline followed by a $4 \%$ paraformaldehyde $-2 \%$ glutaraldehyde solution made in $0.1 \mathrm{M}$ Sorenson's phosphate buffer, $\mathrm{pH}$ 7.2. Saphenous nerve sections were fixed $2 \mathrm{hr}$ at $4^{\circ} \mathrm{C}$ in $3.5 \%$ glutaraldehyde and washed overnight at $4{ }^{\circ} \mathrm{C}$ in $5 \%$ sucrose in Sorenson's buffer. Tissues were post-fixed $1 \mathrm{hr}$ in buffered $1 \%$ osmium tetroxide, rinsed in buffered sucrose, dehydrated in a series of alcohols, washed in propylene oxide, and embedded in Spurr's resin. Blocks were thin sectioned $(60-80 \mathrm{~nm})$, mounted onto carbon-coated Formvar slot grids, stained with uranyl acetate and $0.3 \%$ lead citrate, and examined on a Hitachi (Tokyo, Japan) 7000 transmission electron microscope. All analyses were done on age-matched mice processed in parallel.

\section{RNA expression analysis}

Northern hybridization analysis. Total RNA was isolated using Trizol (Life Technologies, Gaithersburg, MD) extraction followed by isopropanol precipitation. RNAs ( $10 \mu \mathrm{g}$ of brain, $10 \mu \mathrm{g}$ of transgenic skin, and 20 $\mu \mathrm{g}$ of control skin) were separated on agarose-formaldehyde gels, transferred to nitrocellulose membranes, and hybridized to a ${ }^{32} \mathrm{P}-\alpha \mathrm{CTP}-$ labeled antisense riboprobe made to the full-length BDNF cDNA sequence. Hybridization and washes were done as described previously (Albers et al., 1996). Relative band intensities were determined using NIH Image software.

In situ hybridization. In situ hybridization to detect trk receptor expression was done as described previously (Goodness et al., 1997). The trkA template encompassed nucleotides $1187-1547$ of the rat trkA gene and encoded sequences within the extracellular, transmembrane, and intracellular domains of the protein. The trkB template encompassed nucleotides $1362-1558$ of the rat trkB receptor that encoded amino acid sequences within the intracellular domain. The trkC template encompassed nucleotides $1119-1493$ of rat trkC cDNA that encoded protein sequences in the extracellular, transmembrane, and intracellular domains. The relative number of neurons that expressed trkA, trkB, or trkC mRNAs was determined by counting labeled neuronal profiles in which the number of reduced silver grains over the soma was $2 \times$ background levels. The perimeter of labeled profiles was drawn in every tenth section of trigeminal ganglion and every fifth section of DRG using a drawing tube attached to an Olympus Opticals (Tokyo, Japan) microscope. Areas of drawn profiles were captured and calculated using NIH Image software. By assuming circularity of each profile and knowing the section thickness $(20 \mu \mathrm{m})$, the relative frequency distribution of profiles was generated, and the number and size distribution was corrected using the recursive translation computer program (Rose and Rohrlich, 1987; Goodness et al., 1997). Data were analyzed as a two-way ANOVA using Statview software. Differences among means were determined using Fischer's least significant difference analysis.

Reverse transcriptase-PCR. One microgram of DNased RNA was reverse transcribed using Superscript (Life Technologies) and random primers in a $20 \mu \mathrm{l}$ reaction volume. Aliquots of the generated cDNAs were PCR amplified in a $50 \mu \mathrm{l}$ volume by adding $1.5 \mathrm{U}$ Taq polymerase (Promega), PCR buffer, dNTP mix, trkB-specific primers (20 $\mu \mathrm{M}$ each), and $0.2 \mu \mathrm{l}$ of ${ }^{32} \mathrm{P}$-dCTP. A separate reaction to amplify actin was used to serve as an internal standard. Typical reaction conditions were as follows: $1 \mathrm{~min}, 94^{\circ} \mathrm{C}$; $1 \mathrm{~min}, 60^{\circ} \mathrm{C}$; and $2 \mathrm{~min}, 72^{\circ} \mathrm{C}$. The optimal number of cycles (to avoid plateau of reaction) was determined for each primer pair. Quantification of band intensities was done using a Storm phosphorimager and ImageQuant software (Molecular Dynamics, Sunnyvale, CA). Primer sets used were as follows: TrkB full-length, 5'ATAACGGAGACTACACCCTGATGG3' and 5'AGCTGACTGTTGGTGATGCC3' (506 bp); TrkB.T1, 5'CATAAGATCCCACTGGATGGGTAG3' and 5'GCTGCAGACATCCTCGGAGATTAC3'(363 bp); TrkB.T2, 5'CAGAAGTGTGCTTATTTTGC3' and 5'AGACAATACAGGTCTACCTCTCAG3' (854 bp); actin, 5'TAAAACGCAGCTCAGTAACAGTCCG 3' and 3' TGGAATCCTGTGGCATCCATGAAAC 3' (348 bp).

\section{Grain counting methodology}

The percent of somal areas covered by autoradiographic grains was determined as a measure of hybridization signal density and used to indicate the relative amount of trkB mRNA per cell. Images of 25 randomly selected neurons per ganglia (six transgenic and six agematched controls, a total of 300 neurons) viewed using a $40 \times$ oil immersion lens were captured using a CCD camera and imported into the NIH Image morphometric program. Hematoxylin and eosin counterstain was subtracted using a \#47 wratten filter and the "horizontal subtraction" option in the Image program. The "density slice" option was used to threshold each neuron so only autoradiographic grains were selected. Borders of each neuron were drawn, and the percent area covered by grains was measured. Values were averaged and statistical significance tested using a $t$ test.

\section{RESULTS}

K14-BDNF transgenic mice express increased levels of BDNF in specific epithelial targets

BDNF expression was driven using the human keratin K14 promoter to direct high levels of transgene expression to the skin and tongue (Vassar and Fuchs, 1991; Albers et al., 1994; Wang et al., 1997). Onset of promoter activity in whisker pad skin was at E11.5 of mouse development (H. F. Figueiredo and K. M. Albers, unpublished data), a time that overlaps with endogenous neurotrophin expression (Buchman and Davies, 1993). Three founder lines $(737,733$, and 632) identified by Southern hybridization (Fig. $1 A$ ) had three, five, and eight copies, respectively (data not shown). Relative mRNA expression levels were determined by Northern analysis (Fig. 1B) and showed lowest transgene expression in line 737 and higher levels in lines 632 and 733. Control mouse brain, control skin, and skin isolated from each transgenic line expressed endogenous BDNF transcripts at 4.0 and $1.6 \mathrm{~kb}$ (Maisonpierre et al., 1990), whereas transgenic mRNAs only hybridized to a band at $\sim 2 \mathrm{~kb}$, the predicted size of the K14BDNF mRNA. Smaller transgene transcripts were also visible and likely represented alternatively spliced mRNA. The two highest expressing lines (733 and 632) were established by mating F1 offspring to control mice. For line 632, heterozygous offspring were analyzed because homozygous mice reproduced poorly, whereas homozygous offspring from line 733 were used for analysis because they showed no difference in mating efficiency.

\section{BDNF peptide is overexpressed in transgenic skin and retrogradely transported to sensory ganglia}

To verify transgene BDNF peptide synthesis and specificity of transgene expression, BDNF-specific ECLIA and ELISA were used to measure BDNF peptide in various tissues of transgenic and control mice (Table 1). As expected, BDNF peptide was increased in whisker pad skin, dorsal skin, and tongue. In transgenic skin, BDNF peptide was increased up to 9.85 -fold over 
A
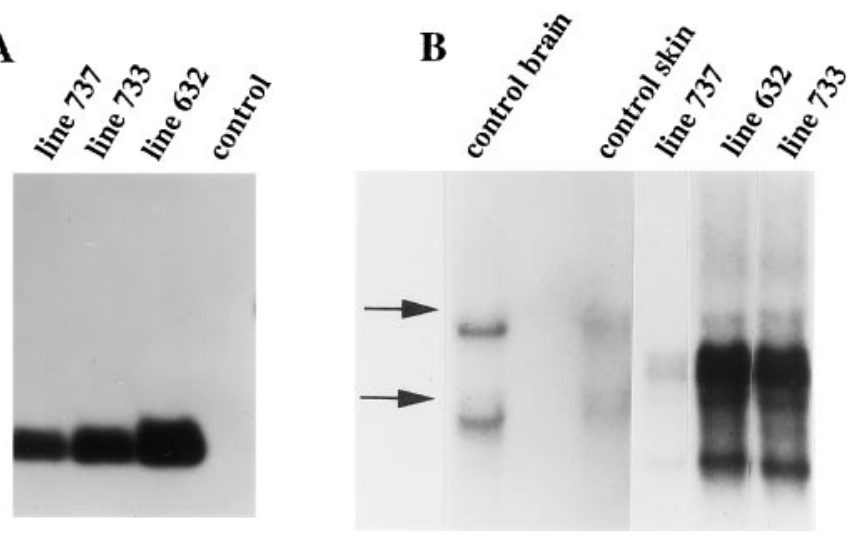

Figure 1. Isolation of K14-BDNF transgenic mice. A, Southern hybridization was used to detect transgene incorporation. Genomic DNA (10 $\mu \mathrm{g}$ ) isolated from tail samples was restriction digested with BamHI, separated on an $0.8 \%$ agarose gel, transferred to nitrocellulose, and hybridized with a random primed ${ }^{32} \mathrm{P}$-dCTP-labeled probe made to the full-length BDNF cDNA. A $770 \mathrm{bp}$ transgene band was detected in lines 737,632 , and 733 and not in control samples. The endogenous BDNF gene was not detectable at this exposure $(24 \mathrm{hr})$. Transgene copy number was estimated by slot blot analysis of $2 \mu \mathrm{g}$ of genomic DNA using a ${ }^{32} \mathrm{P}$-dCTP-labeled random primed probe made to the BDNF cDNA. Band intensity measures were done using NIH Image 1.57 software and nontransgenic DNA samples as standards. Transgenic line 737 had three transgene copies, line 632 had eight copies, and line 733 had five copies. $B$, Northern hybridization analysis was used to detect transgene RNA expression. Total RNA from control brain $(10 \mu \mathrm{g})$, control flank skin (20 $\mu \mathrm{g})$, and transgenic flank skin $(10 \mu \mathrm{g})$ was run on a formaldehyde gel, transferred to a nitrocellulose membrane, and probed with a ${ }^{32} \mathrm{P}-\alpha \mathrm{CTP}-$ labeled riboprobe made to the BDNF cDNA. Endogenous BDNF transcripts ( 4.0 and $1.6 \mathrm{~kb}$ ) were detected in control brain, control skin, and transgenic samples. Transgenic samples (lines 737, 632, and 733) expressed a major transgene transcript of $\sim 2.0 \mathrm{~kb}$. Arrows demarcate migration distance of the 28 and $18 \mathrm{~S}$ ribosomal RNA bands.

Table 1. Measure of BDNF protein in tissues of control and transgenic mice

\begin{tabular}{lccl} 
Assay & Control & $\begin{array}{l}\text { BDNF } \\
\text { transgenic }\end{array}$ & $\begin{array}{l}\text { Fold } \\
\text { increase }\end{array}$ \\
\hline ECLIA (ng/ml) & & & \\
$\quad$ Whisker pad skin & $0.07 \pm 0.01$ & $0.69 \pm 0.08$ & 9.85 \\
Tongue & Not detectable & $1.60 \pm 0.45$ & - \\
DRG & $0.57 \pm 0.07$ & $1.74 \pm 0.39$ & 3.05 \\
Kidney & $0.08 \pm 0.01$ & $0.07 \pm 0.00$ & None \\
Liver & $0.02 \pm 0.00$ & $0.02 \pm 0.00$ & None \\
Brain & $0.08 \pm 0.01$ & $0.07 \pm 0.00$ & None \\
ELISA (ng/gm) & & & \\
Dorsal skin $(n=12)$ & $1.067 \pm 0.095$ & $4.61 \pm 0.589$ & 4.32 \\
Trigeminal $(n=3)$ & $9.26 \pm 0.498$ & $25.15 \pm 1.48$ & 2.71 \\
Nodose-petrosal & & & \\
$\quad($ pooled samples, $n=2)$ & 6.00 & 28.55 & 4.75 \\
$\quad$ SCG $(n=3)$ & $23.49 \pm 3.99$ & $23.03 \pm 2.08$ & None \\
\hline
\end{tabular}

BDNF protein levels were measured using both ECLIA (nanograms per milliliters tissue extract) and ELISA (nanograms per grams wet weight). Levels were significantly increased in whisker pad and dorsal skin, trigeminal, nodose-petrosal, and dorsal root ganglia, and tongue of transgenic mice. BDNF levels were unchanged in SCG, kidney, liver, and brain. For ECLIA measures, samples size was $n=3$. Values are mean \pm SEM.

control levels (0.69 vs $0.07 \mathrm{ng} / \mathrm{ml} ; p<0.01)$ (Table 1$)$, whereas tongue tissue showed even higher levels $(1.60 \pm 0.45 \mathrm{ng} / \mathrm{ml})$. BDNF peptide level was also increased in trigeminal, nodosepetrosal, and dorsal root ganglia, indicating retrograde transport of peptide from the epithelium because the K14-driven transgene was not expressed in neurons (Davis et al., 1994). No change in BDNF level was measured in the SCG, brain, kidney, or liver of transgenics (Table 1).

\section{Increased expression of BDNF in skin alters sensory innervation}

Previous studies of overexpressor transgenic mice have shown NGF and NT-3 enhance sensory innervation and end organ development in specific manners (Albers et al., 1994, 1996; Davis et al., 1996). To determine whether BDNF overexpression affected skin innervation, histological and immunological analyses of postnatal day 7 (P7) and adult whisker pad and flank skin were done (see also (Rice et al., 1998). Hematoxylin and eosin staining of control (Fig. 2A) and transgenic (Fig. 2B) skin showed transgenics had an increased density of cells around hair follicles. The morphology of these cells and their overlap with increased nerve innervation surrounding hair follicles (Fig. 2D,F) suggest they are Schwann cells. Interestingly, comparison of P7 skin with adult skin showed a retraction from the epidermis of small unmyelinated fibers in the adult, although hyperinnervation to hair follicles was maintained (Fig. 2, E, control, $F$, transgenic). Fiber retraction from epidermis and subepidermal regions and increased hair follicle innervation were also apparent in flank skin (data not shown).

As a comparison to hairy skin, sensory innervation to nonhairy glabrous skin of the front foot pad was examined. A principal sensory component of glabrous skin are Meissner touch corpuscles, which are encapsulated sensory mechanoreceptors innervated by rapidly adapting fibers that respond to slight deformation of the skin (Perl, 1992). Immunolabeling using PGP9.5 was used to visualize innervation to Meissner corpuscles in skin overlying the eccrine sweat glands (Fig. 3). Transgenic corpuscles (Fig. $3 B, D)$ were clearly larger and more densely innervated compared with control samples (Fig. $3 A, C$ ). Other PGP9.5-positive endings in the epidermis that appeared nonencapsulated were also enhanced in BDNF skin (Fig. 3A, B, arrowheads). Using hematoxylin and eosin staining, Meissner-like sensory corpuscles were also found in shallow dermal papilla located laterally to the sweat glands (Fig. 3E, control). In comparable regions of BDNF transgenic skin (Fig. $3 F$ ), these Meissner-like corpuscles were found to be unusually large. Transgenic corpuscles were associated with an increased number of lamellar cells (Fig. $3 F$, arrows), which are thought to be modified Schwann cells of neural crest origin (Vega et al., 1996). Although the size and innervation to Meissner corpuscles was increased, no overt change in the number of endings was apparent.

In comparing the innervation of BDNF and control foot pad skin, an evident increase in the number of PGP9.5-positive cells and fibers aligned along the dermal-epidermal border was also noted (Fig. 4, $A$, control, $B$, transgenic). This location and the finding that these cells labeled with the Merkel cell-specific marker keratin K20 (Fig. 4C,D) identified them as Merkel cells (Moll et al., 1995; Navarro et al., 1995). Merkel cell number with associated innervation was clearly increased in the transgenic skin and in many fields were found in clustered arrangements, suggesting BDNF-enhanced Merkel cell duplication during maturation of the skin. This finding is interesting in light of previous studies that showed that Merkel cells associated with touch dome mechanoreceptors in dorsal skin were dependent on skin-derived NT-3 (Airaksinen et al., 1996; Albers et al., 1996) and suggested that Merkel cells were either responsive to both BDNF and NT-3 

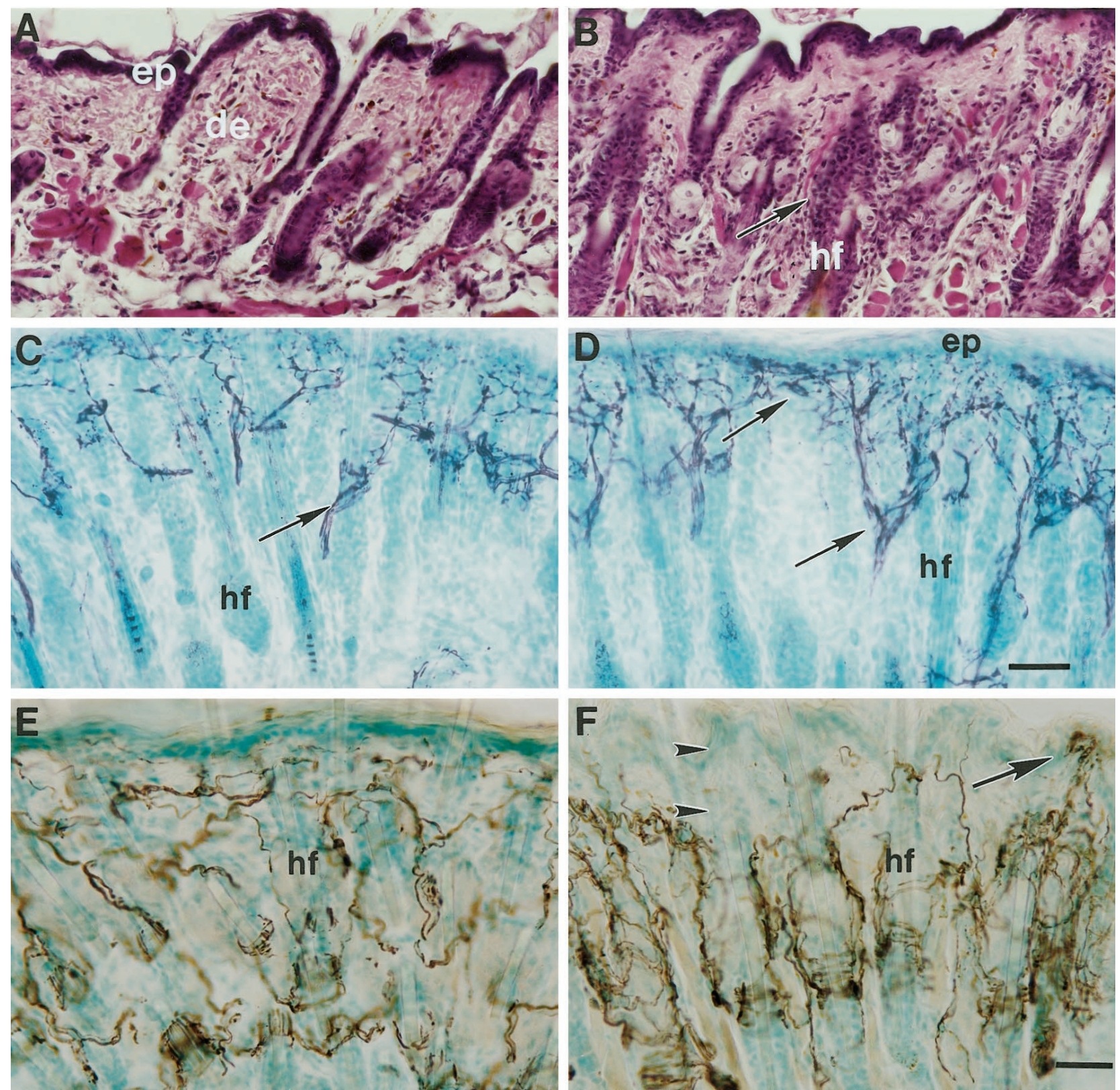

Figure 2. Histology and innervation of BDNF transgenic skin. Comparison of adult flank skin of control $(A)$ and BDNF transgenic $(B)$ mice stained with hematoxylin and eosin showed that transgenic skin had increased cellularity in the dermis and surrounding hair follicles (arrow in $B$ ). Innervation density was assessed in P7 and adult mice by labeling thick sections $(40 \mu \mathrm{m})$ of skin from whisker pad with an antibody against PGP9.5. Compared with control whisker pad skin $(C)$, skin of P7 transgenic mice $(D)$ had larger nerve bundles (arrows) and increased fiber density in epidermis and subepidermal regions of the skin, particularly around hair follicles. Adult transgenic whisker pad skin $(F)$ also had increased density of PGP9.5-positive fibers around hair follicles compared with control skin $(E)$. In addition, many regions showed fiber withdrawal from the epidermis and subjacent dermal regions (between arrowheads), although cluster endings in the epidermis (arrow) remained. $D e$, Dermis; $e p$, epidermis; $h f$, hair follicle. Scale bars: (in $D$ ) $A-D$, $100 \mu \mathrm{m}$; (in $F$ ) $E, F, 50 \mu \mathrm{m}$.

or that Merkel cells in foot pad and backskin had differing trophic dependencies. To test these possibilities, we assayed the number of Merkel cells in BDNF backskin and, interestingly, found no significant difference $(p=0.21)$ in Merkel cell number between control $(14.1 \pm 2.5 ; n=3)$ and BDNF transgenic $(16.8 \pm 1.6 ; n=$ 3) touch domes. These findings indicate that Merkel cells have site-specific trophic dependencies and support previous findings of heterogeneity in this neuroendocrine cell population (Nurse and Farraway, 1988).

\section{Sensory neuron populations are differentially affected by BDNF overexpression}

Transgenic mice that overexpressed either NGF or NT-3 had increased numbers of neurons in DRG and trigeminal ganglia that resulted from a decrease in developmental cell death (Figueiredo and Albers, unpublished data). We were therefore surprised to find in our analysis of BDNF ganglia that no change in the number of trigeminal or DRG neurons in BDNF occurred (Table 2), because BDNF is known to support the survival of 

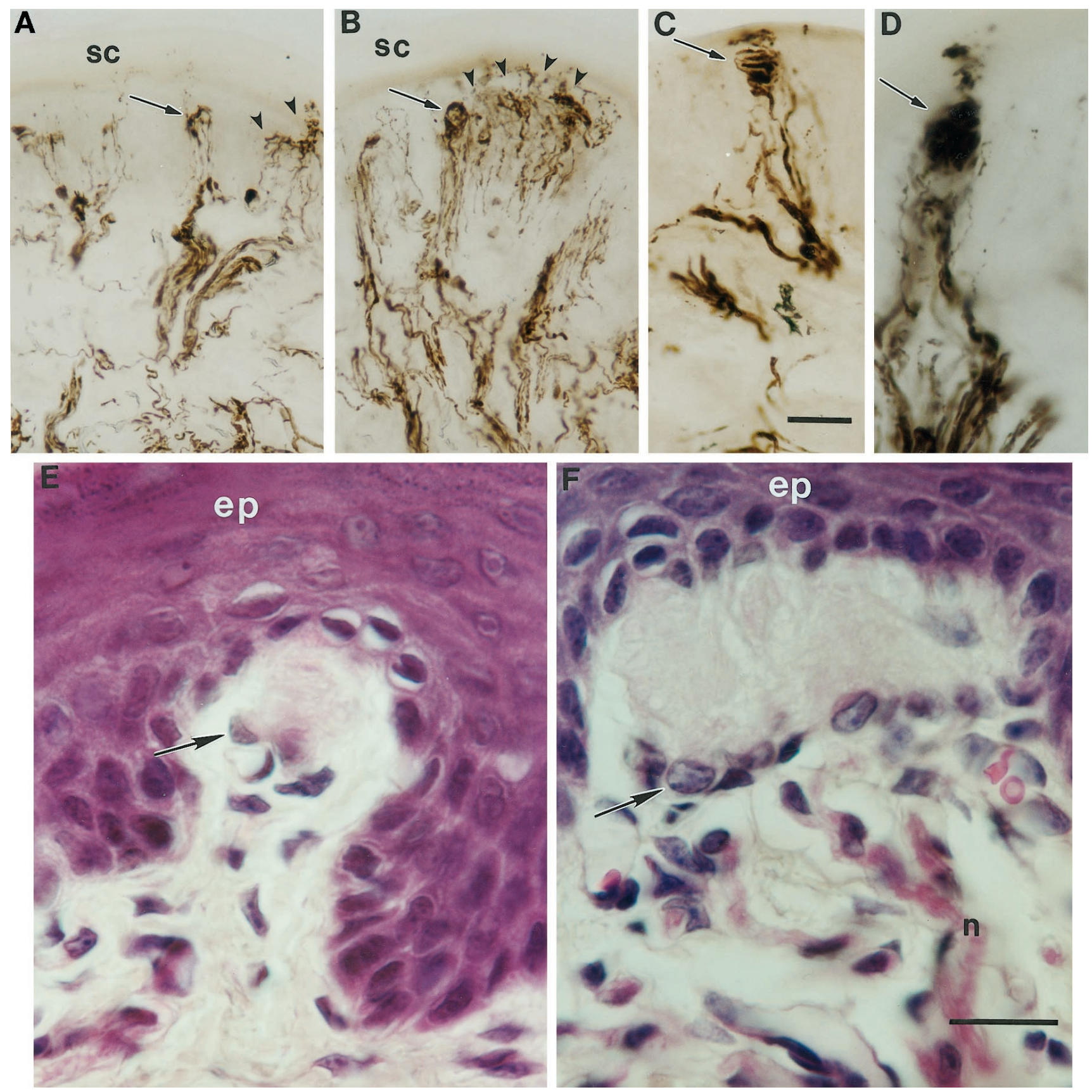

Figure 3. To determine whether BDNF affected sensory nerve innervation of glabrous skin, front foot pad skin from control $(A, C)$ and transgenic $(B$, $D$ ) mice was immunolabeled with an antibody against PGP9.5. BDNF foot pads had increased innervation to Meissner corpuscles (arrows in $A-D$ ) and unencapsulated endings (arrowheads) in the upper epidermis. $C$ (control) and $D$ (transgenic) show enlarged view of Meissner endings. Meissner endings with associated lamellar cells (arrows) were also found between pad regions in controls $(E)$ and transgenics $(F)$. Note enlargement in transgenic endings. $s c$, Stratum corneum; $e p$, epidermis; $n$, nerve fiber. Scale bars: $C, 40 \mu \mathrm{m} ; F, 20 \mu \mathrm{m}$.

mouse embryonic DRG and trigeminal neurons in cell culture (Buchman and Davies, 1993), and BDNF knock-out mice showed reduction of neurons in trigeminal ganglion (44 and 27\%) and L4 DRG (30 and 34\%) (Ernfors et al., 1994; Jones et al., 1994, respectively). To directly examine whether axonal projections to the skin were altered, we counted the number of myelinated and unmyelinated axons in the cutaneous saphenous nerve (composed of axons from lumbar dorsal root ganglia L2 and L4) (Table 3). Myelinated axon profiles in BDNF and control samples were nearly identical in number (controls, $610 \pm 28$; $n=7$; vs transgenics, $606 \pm 21 ; n=5 ; p=0.9353)$, a result consistent with the unchanged axon counts measured in BDNF knock-out mice by Carroll et al. (1998). Surprisingly, BDNF overexpressors did have a statistically significant $25 \%$ decrease in unmyelinated axon counts (controls, $3318 \pm 158$; vs transgenics, $2663 \pm 213 ; p=$ 0.0233 ), although no change in DRG neuron number was measured. Although no definitive explanation for this loss can be given at this time, this reduction may be related to the BDNFinduced withdrawal of unmyelinated fibers from the epidermis and upper dermis (Fig. $2 F$ ), suggesting that chronic exposure of nerve terminals to BDNF may induce fiber retraction but not cause neuronal death. Another possibility is that the lost unmy- 

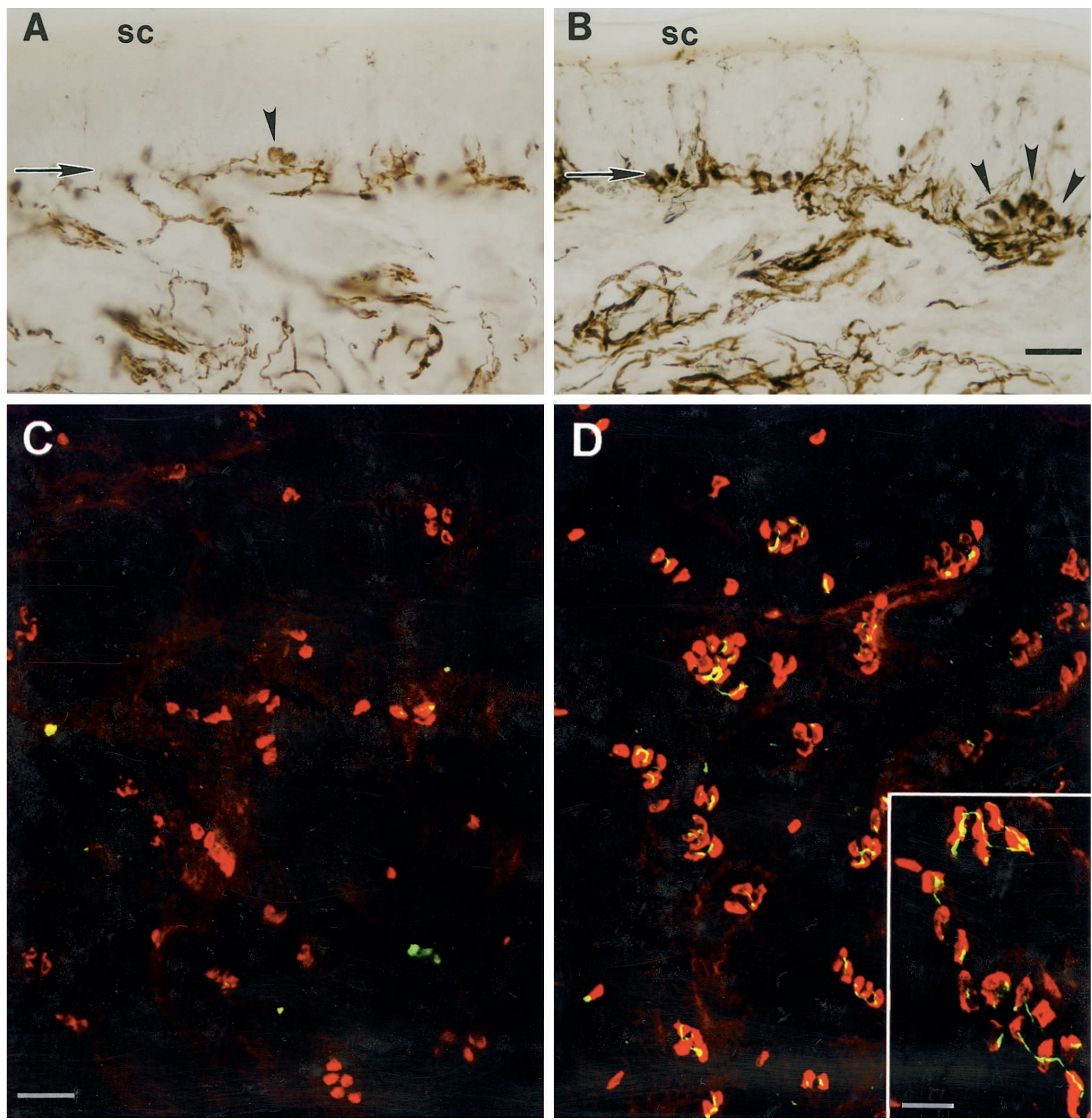

Figure 4. The number of Merkel cell endings in the foot pad are increased in BDNF overexpressors. Sections of control $(A)$ and transgenic $(B)$ foot pad skin labeled with anti-PGP9.5. Merkel cells at the dermal-epidermal border are marked by arrows in $A$ and $B$. A large Merkel cell cluster in $B$ is indicated by arrowheads. To better view the distribution of Merkel cells, foot pad epidermis of control $(C)$ and transgenic $(D)$ mice was separated from the underlying dermis and Merkel complexes double-labeled using an anti-keratin K20 and anti-neurofilament NF150 antibody. Note increase in the number of individual Merkel cells and their clustering into discrete units $(D)$, similar to those marked by arrowheads in $B$. Inset shows magnified image of transgenic skin; areas of Merkel cell and nerve terminal overlap appear yellow. Scale bars: $B, 40 \mu \mathrm{m} ; C, 100 \mu \mathrm{m}$; inset, $15 \mu \mathrm{m}$.

elinated axons are sympathetic fibers running through the saphenous nerve and that increased BDNF caused their selective reduction. This seems unlikely, however, because (1) no loss of sympathetic neurons was measured in the superior cervical ganglia (Table 2), and (2) labeling of sympathetic fibers in transgenic backskin using an anti-tyrosine hydroxylase antibody indicated sympathetic projections were slightly increased compared with control skin (data not shown). A similar increase was reported by Botchkarev et al. (1998) for subsets of sympathetic innervation in mice overexpressing BDNF in muscle.

To determine whether transgene-derived BDNF supported neuronal populations known to be dependent on BDNF for survival, we also counted neurons in the placode-derived nodosepetrosal sensory ganglia (Table 2). An increase in neuron number was found in the NPG, a complex composed of the fused superior and inferior vagal ganglia and petrosal ganglion whose sensory neurons project to the tongue and visceral organs (e.g., esophagus, stomach, and intestine) (Neuhuber, 1987). NPG neurons have a shared dependence on BDNF and NT-4 and are reduced $(47 \%)$ in BDNF knock-out mice (Erickson et al., 1996). Because K14-BDNF was expressed at high levels in tongue and BDNF peptide was elevated in the NPG (Table 1), an enhanced target- 
Table 2. Neuronal counts of adult K14-BDNF transgenic and control mice

\begin{tabular}{|c|c|c|c|c|}
\hline Mouse genotype & $\begin{array}{l}\text { Dorsal root ganglia } \\
\text { (L4/L5) }\end{array}$ & Trigeminal ganglia & $\begin{array}{l}\text { Superior cervical } \\
\text { ganglia }\end{array}$ & Nodose-petrosal complex \\
\hline Control & $12,350 \pm 1,411(n=3)$ & $33,433 \pm 3,119(n=3)$ & $14,284 \pm 942(n=3)$ & $4850 \pm 223(n=5)$ \\
\hline BDNF transgenic & $12,177 \pm 1,748(n=3)$ & $34,567 \pm 3,925(n=3)$ & $15,342 \pm 1,008(n=3)$ & $6670 \pm 639 *(n=6)$ \\
\hline
\end{tabular}

Values are shown for BDNF transgenic line 632. Statistical significance was determined using a $t$ test; values are expressed as SEM.

*Indicates significance $(p<0.05)$.

derived support to transgenic NPG neurons was feasible. Neuronal counts did indeed show that NPG ganglia of transgenics had $38 \%$ more neurons than control ganglia $(6670 \pm 639$ vs $4850 \pm$ 223; $p<0.05)$. In addition, size distribution analysis of neurons comprising the NPG ganglia showed transgenic neurons were, across all size classes, larger than control neurons (BDNF, $24 \mu \mathrm{m}$; vs control, $20.5 \mu \mathrm{m}$ diameter; $p<0.0001$; Kolmogorov-Smirnov; $n=3$ mice per group). Thus, BDNF increased the number and size of NPG neuronal populations but had no affect on the number of neurons comprising either trigeminal, DRG, or sympathetic ganglia.

\section{Trk receptor expression is altered in trigeminal and DRG of BDNF overexpressors}

The biological response of sensory neurons to neurotrophins is mediated by the family of trk receptor tyrosine kinases (Barbacid, 1994). Neurotrophins signal through trk receptors in specific manners, such that trkA preferentially binds NGF, trkC binds NT-3, and trkB binds BDNF and NT-4. Studies of mice that overexpress NGF and NT-3 in the skin have shown that, in vivo, increased ligand expression can cause a doubling in the percent of neurons that expressed mRNAs encoding the cognate receptors (trkA and trkC, respectively) (Albers et al., 1996; Goodness et al., 1997). This increase in trk-expressing neurons could be explained by the increased survival of the respective neuronal population, as indicated by the increase in total neuron number in the NGF and NT-3 lines. BDNF mice did not have an increase in neuron number, raising the question of whether trkB expression would be modified in sensory neurons of the BDNF transgenics. In situ hybridization to examine expression of the full-length trkB receptor mRNA showed BDNF-overexpressors did have a statistically significant increase in the number of trkB-expressing neurons in trigeminal and DRG ganglia (292 and 60\%, respectively) (Table 4). Because neuron number did not increase (Table 2), increased levels of BDNF in the skin must have caused upregulation of trkB mRNA in neurons that normally were either trkBnegative or expressed trkB at undetectable levels, i.e., phenotypic switching to a trkB phenotype must have occurred. This interpretation is also supported by grain counting analysis of neurons processed for in situ hybridization, which showed trkB expression did not change on a per cell level, i.e., the average somal area covered by autoradiographic grains was not significantly different

\begin{tabular}{l}
$\begin{array}{l}\text { Table 3. Counts of saphenous axon counts in K14-BDNF transgenic } \\
\text { and control mice }\end{array}$ \\
\begin{tabular}{lll} 
Mouse genotype & Myelinated & Unmyelinated \\
\hline Control & $610 \pm 28(n=7)$ & $3,318 \pm 158(n=7)$ \\
BDNF transgenic & $606 \pm 21(n=5)$ & $2,663 \pm 213^{*}(n=4)$
\end{tabular} \\
\hline
\end{tabular}

$\overline{\text { Values are shown for BDNF transgenic line 632. Statistical significance was deter- }}$ mined using a $t$ test; values are expressed as SEM. $n$, The number of mice analyzed. *Indicates significance $(p<0.05)$. between transgenics $(8.2 \pm 1.0 \%)$ and controls $(7.45 \pm 1.1 \% ; p<$ $0.05)$. The consequence of the trk receptor switching may be reflected, at least in part, by the increased innervation surrounding hair follicles (Fig. 2) and enhanced innervation to Meissner corpuscles and Merkel cells of the foot pad (Figs. 3, 4). Future studies to define the physiological profile of neuronal populations in the BDNF skin will determine whether this is the case.

Receptor binding studies and analysis of trk expression in BDNF gene knock-out mice indicates BDNF also interacts with and activates the trkA receptor (Rodriguez-Tebar et al., 1990; Liebl et al., 1997). In particular, BDNF mutants showed a 20$30 \%$ loss of trkA-expressing neurons, which may reflect dependence of some trkA neurons on BDNF during development. In support of these findings, our in situ analysis showed that overexpression of BDNF increased the trkA-expressing population by $70 \%$ in trigeminal ganglia (Table 4). In addition, size distribution analysis of trkB-positive neurons in the trigeminal ganglia showed that the number of trkB neurons was increased in all size ranges (Fig. 5A), with many in the small cell population $(13-15 \mu \mathrm{m})$. Similarly, an increased number of trkA-positive neurons was also found, primarily in the small-sized neuronal populations (13-15 $\mu \mathrm{m})$ (Fig. $5 B$ ), suggesting overlap of the trkA and trkB populations. In contrast, no change in either the number or size distribution of the trkC population was found (data not shown).

\section{TrkB receptor isoform expression is modified by overexpression of BDNF}

Alternative RNA splicing generates at least three trkB isoforms that all bind BDNF (Klein et al., 1990a; Middlemas et al., 1991). The full-length tyrosine kinase form, trkB.FL, contains an extracellular ligand-binding domain, a transmembrane domain, and a tyrosine kinase-containing intracellular domain. Truncated forms, trkBT.1 and trkBT.2, contain extracellular and transmem-

Table 4. Relative number of trk receptor neurons in sensory ganglia

TrkB neurons TrkA neurons TrkC neurons

\begin{tabular}{lcll}
\hline Trigeminal & & \\
$\quad$ Control $(n=11)$ & $56 \pm 6$ & $121 \pm 20$ & $144 \pm 26$ \\
Line $632(n=9)$ & $164 \pm 26^{*}$ & $215 \pm 36^{*}$ & $220 \pm 42$ \\
L4 DRG & & & \\
Control $(n=7)$ & $53 \pm 7$ & $177 \pm 27$ & $110 \pm 12$ \\
Line 632 $(n=9)$ & $85 \pm 8^{*}$ & $236 \pm 32$ & $147 \pm 16$
\end{tabular}

In situ hybridization was performed on control and transgenic ganglia using ${ }^{35} \mathrm{~S}$ labeled riboprobes to either trkA, trkB, or trkC mRNA. Positive neurons were counted in every 10 th section of serial sectioned ganglia, and neuronal counts were corrected using recursive translation. In trigeminal ganglia, line 632 had a $292 \%$ increase in the number of trkB-expressing neurons $(p \leq 0.05)$ and a $70 \%$ increase in trkA-expressing neurons $(p<0.05)$. Transgenic DRG had a $60 \%$ increase in trkB neurons, although no significant difference in the number of trkA neurons. Both ganglia had no statistically significant change in trkC neurons. Counts are $\pm \mathrm{SEM}$. *Indicates significance $(p<0.05)$. 
A

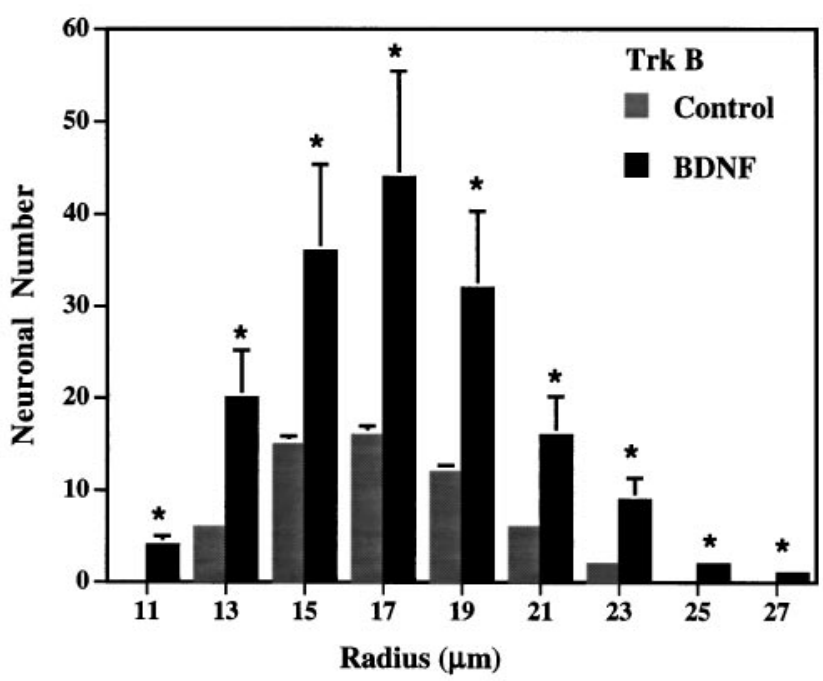

B

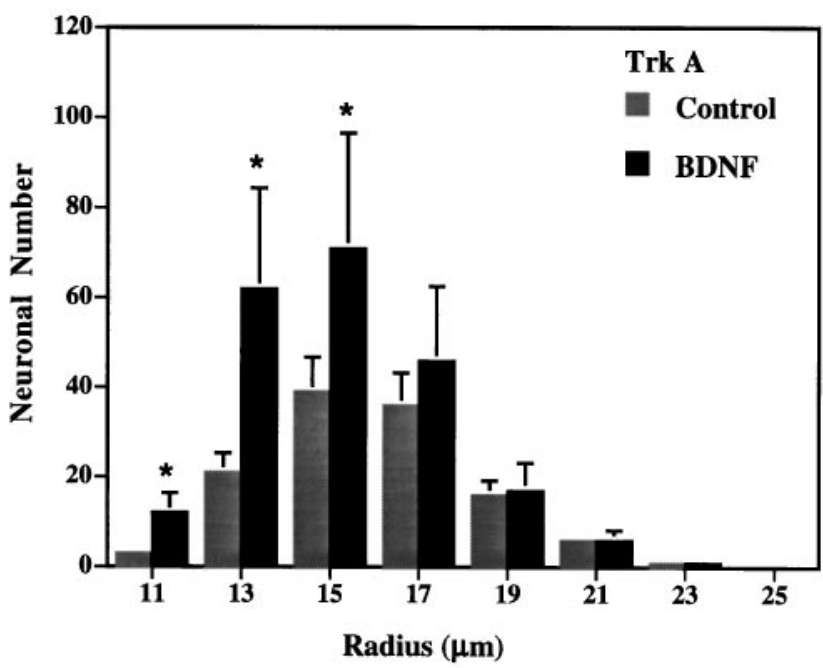

Figure 5. Size distribution of trk receptor-expressing neurons in trigeminal ganglia. Size distributions of trkB- and trkA-expressing neurons of trigeminal ganglia from K14-BDNF transgenic and control mice are plotted as the number of cells per radius. In transgenic trigeminal ganglia $(A)$, trkB neurons were increased in all size ranges (11-27 $\mu \mathrm{m}$ radius). TrkA neurons in transgenic ganglia were predominantly in the small neuron (13-15 $\mu \mathrm{m})$ populations, indicating that small trkA neurons were most affected by increased BDNF. Data were analyzed using the Kolmogorov-Smirnov statistic to identify differences in size distributions as in Goodness et al. (1997). Asterisks denotes bins in the trkA distribution $(B)$ that had statistically significant increases in the number of trkA neurons.

brane domains but lack intracellular kinase domains. The kinase domain is replaced by two unique short sequences containing 23 (trkBT.1) or 21 (trkBT.2) amino acids (Middlemas et al., 1991). Truncated isoforms are proposed to modulate BDNF activity by sequestering it from the surrounding tissue and thereby reducing full-length trkB binding (Biffo et al., 1995). Similarly, truncated forms may also negatively regulate kinase signaling by forming nonf unctional, heterodimer (full-length and truncated) receptor complexes (Eide et al., 1996). In addition, cellular level physiology measures have suggested truncated forms may stimulate kinase signaling pathways, as measured by generation of glycolytic and respiratory products (Baxter et al., 1997). In vivo, truncated trkB receptor expression is upregulated in developing neurons and in response to injury, suggesting a role for truncated forms in regulating the impact of BDNF on neuron development and repair processes (Ninkina et al., 1996; Wheeler et al., 1998a).

To determine whether increased levels of BDNF in the skin affected receptor isoform expression in sensory populations, the relative level of mRNAs encoding each isoform was measured using Northern hybridization and reverse transcriptase-PCR (RT-PCR) (Fig. 6). Northern analysis using either a probe that recognized all forms of trkB (kinase and truncated) (Fig. 6A, TrkB-all) or a probe specific for the full-length kinase form (Fig. $6 A$, TrkB.FL) detected numerous splice variants, as documented previously (Klein et al., 1990a). Densitometric analysis of specific bands $(8.2$ and $5.5 \mathrm{~kb})$ showed transgenic ganglia had approximately double the amount of both full-length and truncated mRNAs, which was consistent with the increase in trkBexpressing neurons detected by in situ hybridization.

To determine more precisely the expression levels of trkB mRNAs in trigeminal ganglia, RT-PCR using primers specific for full-length (trkB.FL) and truncated (trkB.T1 and trkB.2) mRNAs was performed. cDNAs generated by reverse transcription were PCR amplified in the presence of ${ }^{32} \mathrm{P}$-dCTP, and product levels were quantified using a phosphorimager (Fig. 6B). Image analyses showed transgenic ganglia had approximately double the amount of trkB.FL mRNA compared with control ganglia and that truncated trkB.T1 was expressed at levels slightly above control (0.19-fold; $p<0.05)$, whereas trkB.T2 was unchanged.

TrkB protein levels were also increased in transgenic mice as measured by Western immunoblotting of protein samples isolated from trigeminal ganglia and nerves projecting to the periphery (Fig. 6C). Densitometric measure of bands representing the 145 $\mathrm{kDa}$ full-length form and $95 \mathrm{kDa}$ truncated form showed fulllength trkB was slightly increased in transgenic ganglia and virtually undetectable in nerve. Truncated forms predominated in control and transgenic ganglia and appeared slightly increased in transgenic ganglia ( $\sim 25 \%$ by densitometry) (Fig. $6 C$, left panel). Interestingly, the amount of truncated trkB protein was doubled in nerve fibers projecting to the skin (Fig. 6C, right panel). Collectively, these results indicate that synthesis and peripheral transport of truncated trkB, which from RT-PCR analysis was most likely TrkB.T1, was enhanced in BDNF transgenics.

\section{K14-BDNF transgenic mice showed no change in nociceptive behavioral response}

BDNF has been implicated as a regulatory molecule of pain and mechanosensation (Siuciak et al., 1994; Zhou and Rush, 1996; Carroll et al., 1998). This possibility and the preferential increase in small-diameter neuron populations in BDNF transgenic ganglia prompted us to measure nociceptive responses in BDNF mice. Temperature sensitivity was measured using a hot plate set at $52^{\circ} \mathrm{C}$ on eight transgenic and eight control mice tested over 4 consecutive days (Fig. 7A). Although control mice averaged a 26.7 sec latency and transgenic mice averaged a $23.5 \mathrm{sec}$ latency, this trend was not statistically significant.

Nociceptive behavioral response to mechanical stimulation was also tested in BDNF transgenic mice by measuring von Frey hair thresholds on foot pad skin. Mice were tested over a $4 \mathrm{~d}$ period, and the response data was plotted using the Kolmogorov-Smirnov analysis (Davis et al., 1993). Similar to thermoception, no statistically significant change in behavioral response was measured in BDNF transgenic mice (Fig. 7B).

Although no change in nociceptor response was elicited, it is likely that, given the increased neurite innervation to hair folli- 
Figure 6. Expression of trkB isoforms in BDNF transgenic neuronal tissues. $A$, Northern blot analysis of RNA from transgenic and control trigeminal ganglia was done using a probe that detected mRNAs encoding both full-length and truncated trkB forms (TrkB-all) or mRNAs encoding only full-length forms (TrkB.FL). Hybridization signals for mRNAs encoding both full-length and truncated forms were increased compared with control samples. Signal density measures were normalized to actin. $B$, To better quantify relative levels of expression, RT-PCR analysis of trigeminal RNA from control and transgenic mice was done using primers specific for fulllength trkB (trkB.FL) and truncated forms (trkB.T1 and trkB.T2). Shown are representative data from a total of six transgenic and six control mice analyzed. ImageQuant software was used to measure band intensity and showed that trkB.FL and trkB.T1 were increased in transgenic ganglia 1.8and 0.19-fold, respectively. A control brain sample was used as an internal standard for primer specificity and reaction efficiency. Values were normalized to actin. $C$, Western analysis of trkB expression in control and transgenic trigeminal ganglia (left) and infraorbital nerve (ION) (right) showed prominent expression of the $95 \mathrm{kDa}$ isoform compared with the full-length $145 \mathrm{kDa}$ form. Densitometric measures showed a modest increase $(\sim 25 \%)$ in truncated trkB in transgenic ganglia (two samples per group shown), whereas transgenic ION samples had double the amount of truncated trkB compared with control nerve samples. This distribution suggests truncated forms were preferentially transported to the periphery. Protein samples from brain indicate mobility of the trkB isoforms. Mrk, Molecular weight standards.

cles, Merkel cells, and Meissner corpuscles, changes in sensory perception occurred in BDNF overexpressors. At present, no behavioral testing paradigm for measure of these slowly and rapidly adapting mechanoreceptors is available, although future in vitro electrophysiological assays using an isolated skin preparation are planned to examine possible alteration of the sensory neuron population.

\section{DISCUSSION}

Previous studies of transgenic mice that overexpressed either NGF or NT-3 in a target-derived manner showed these neurotrophins caused a significant increase in the survival of trigeminal and DRG neurons and altered sensory innervation to the skin (Albers et al., 1994, 1996). These changes were consistent with cell culture and gene knock-out studies showing these neurotrophins supported developing embryonic neurons in culture and were survival factors for specific types of sensory neurons. To determine whether increased levels of target-derived BDNF could also impact neuron survival, transgenic mice that overexpressed BDNF in the skin were analyzed. In contrast to NGF and NT-3, overexpression of BDNF did not increase the number of trigeminal or DRG neurons, although it did induce a $38 \%$ increase in the placode-derived nodose-petrosal ganglia complex, a result consistent with the $43-66 \%$ loss of nodose neurons in BDNF knock-out mice (Ernfors et al., 1994; Jones et al., 1994; Erickson et al., 1996). Thus, NPG neurons and neurons of cranial and spinal ganglia appear to have inherent differences in their response to target-derived BDNF; NPG neurons had increased survival, whereas survival of cranial and spinal sensory neurons was unaffected.
That the number of trigeminal and DRG neurons was unchanged in BDNF overexpressors was surprising in light of neuron counts of BDNF and trkB knock-out mice, which showed a 20-44\% neuronal loss in these ganglia (but see Silos-Santiago et al., 1997). The simplest explanation for the lack of BDNFinduced enhancement of trigeminal and DRG neurons would be that BDNF produced by the skin does not function as a targetderived survival factor for developing sensory neurons that innervate the skin but rather as a regulator of neuronal differentiation once their axons reach their target. This would agree with studies of LoPresti and Scott (1994) that showed BDNF had slight affect on survival of chicken cutaneous neurons and suggests neurons other than cutaneous types are lost in the BDNFdeficient DRG and trigeminal ganglia.

That skin-derived BDNF does not increase trigeminal and DRG neuron survival implies that trkB neurons must either be supported by ganglionic sources of BDNF, i.e., in an autocrine or paracrine manner, or that other growth factors, such as NGF or NT-3, are required for embryonic survival of trkB neurons. Autocrine or paracrine modes of support are less likely because expression of BDNF in sensory (trigeminal) ganglia was not detected by in situ hybridization until $\sim$ E14.5 (Schecterson and Bothwell, 1992), a time past when developing neurons are lost in BDNF mutants ( $\sim$ E13.5 in L4 DRG) (Liebl et al., 1997). If, on the other hand, NGF and NT-3 neurotrophins support developing trkB neurons, overlap of trkB with trkA and trkC receptor expressing populations would be expected. Indeed, recent studies by Farinas et al., (1998) of E11 mouse L1 DRG support this possibility, because $70 \%$ of developing neurons express trkC, $40 \%$ 
A

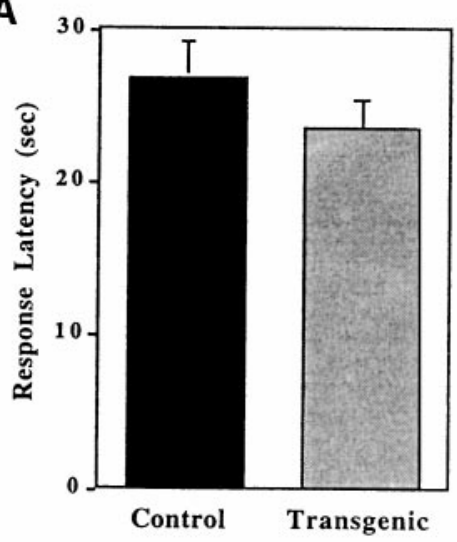

B

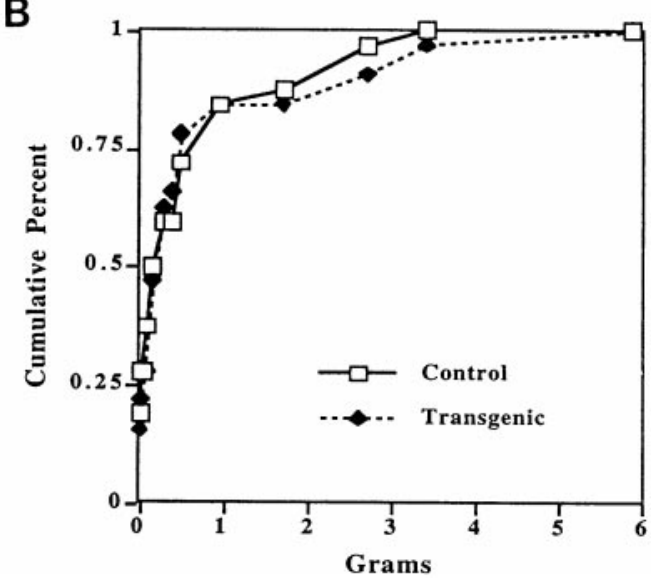

Figure 7. Measure of nociceptive behavior of control and BDNF transgenic mice. Hot plate tests were used to determine whether peripheral overexpression of BDNF affected nociception. Mice were placed on a $52^{\circ} \mathrm{C}$ heated surface, and the time interval between placement and a behavioral escape response (i.e., paw lick or jump) was measured. Response latencies compared using ANOVA showed no significant difference between control and transgenic mice $(A)$. Measures of mechanical sensitivity were done using von Frey hair analysis by placing mice on a platform of mesh material and applying filaments of increasing stiffness to the plantar surface of the hind paw to elicit a response (i.e., twitching or licking of paw). BDNF transgenics $(n=8)$ and controls $(n=8)$ were tested over 4 consecutive days, and the distribution of thresholds was compared using the Kolmogorov-Smirnov statistic $(B)$. No statistically significant difference in response to mechanical stimuli between transgenic and control mice was measured.

express trkB, and $20 \%$ express trkA. By E13, a major shift in expression was found, and only $8 \%$ of neurons expressed trkB, whereas $80 \%$ expressed trkA, suggesting a switch in the neurotrophin responsiveness from NT-3 to NGF. Also important is the finding that, in E11 DRG, 40\% of trkB-expressing neurons are lost in NT-3-deficient mice (Farinas et al., 1998), demonstrating an early dependence of at least some trkB neurons on NT-3 (Conover et al., 1995). Thus, these data are consistent with a model in which trkB neurons are initially supported by NT-3. However, our studies of adult BDNF transgenic ganglia showed an increased number of trkB and trkA neurons, suggesting NGF may also have acted as a trkB neuron survival factor during the later period of neuronal death (E13-E15). If this is the case, the neurons affected would express both trkB and trkA, a likely possibility because $80 \%$ of E13 neurons were trkA-positive (Farinas et al., 1998). A model consistent with these data would be one proposed by Buchman and Davies (1993) in which the type of neurotrophin support required by sensory neurons varies temporally, i.e., NT-3 would support early (E11) trkB neuron survival, whereas NGF would supports late (E13-E15) trkB neuron survival. In this paradigm, increased target-derived BDNF would have no effect on survival and, because endogenous levels of NGF and NT-3 remain at normal levels, no increase in cell number would be expected.

Although not a target-derived survival factor for cutaneous neurons, skin-derived BDNF did influence the establishment and maintenance of sensory endings in the periphery. Thus, skin of postnatal transgenic mice showed prominent hyperinnervation to the epidermis and hair follicles. Interestingly, this epidermal hyperinnervation retracted to lower dermal layers of the skin as it matured. Although the cause of this retraction remains to be determined, one possibility is that increased BDNF in epidermis was repulsive to matured nerve endings. Precedent for such an effect is found in studies of embryonic neurons grown in culture. In vitro application of BDNF to neurite growth cones of rat DRG explants grown in NGF-containing media caused dramatic retraction of lamellipodia and cessation of neurite growth (Paves and Saarma, 1997), suggesting BDNF was inhibitory to NGFresponsive endings. Because many unmyelinated peptidergic endings that innervate the epidermis are NGF-dependent, these terminals may be most affected, i.e., repulsed, by the increased epidermally supplied BDNF. This retraction of nerve fibers appeared specific to the epidermis and subjacent dermis, because dermal regions surrounding hair follicles remained hyperinnervated in the adult BDNF skin.

The retraction of fibers in transgenic hairy skin contrasted with that seen in glabrous foot pad skin in which fiber withdrawal was not observed. In fact, in foot pad there was a marked increase in Merkel cells and their associated nerve terminals. This finding is of interest because (1) Merkel cell complexes are known to require NT-3 for their development, and (2) studies of BDNF $(+/-)$ mice showed electrophysiological impairment of slowly adapting mechanoreceptors (SAMs) that innervate Merkel cells (Carroll et al., 1998). Although reduced BDNF impaired SAM responses, it was not a survival factor for SAMs, because no change in Merkel complexes of backskin nor reduction in myelinated axon number in the saphenous nerve of BDNF knock-outs were found. Our measures are in partial agreement with this interpretation, because no change in myelinated axon number nor number of Merkel cells in backskin of BDNF transgenics were found. Interestingly, this was not the case in foot pad skin in which Merkel cell-neurite complexes were markedly increased in density, suggesting a site-specificity of BDNF action on Merkel cell endings. This site-specific response to BDNF is consistent with comparative studies of Merkel cells in rat backskin and foot pad, which showed different responses to denervation, i.e., denervation caused loss of Merkel cells in backskin but did not affect Merkel cell number in foot pads (Nurse and Farraway, 1988; Mills et al., 1989). Thus, Merkel endings in hairy and glabrous skin may be trophically regulated in distinctly different manners, e.g., foot pad Merkel cells may respond in a paracrine manner to BDNF, whereas backskin Merkel cells do not, and this regulation may confer different physiological properties appropriate for the skin location.

Another sensory ending clearly affected by BDNF overexpression was the foot pad Meissner corpuscle. Although the number of these low-threshold rapidly adapting mechanoreceptors appeared unchanged, the complexity and size of the sensory projection to these endings was greatly enhanced. Once again, 
BDNF did not act as a survival factor but may act instead to influence sensitivity of Meissner endings by enhancing neurite ending morphology. Interestingly, Meissner endings were also enlarged in NT-4 overexpressing transgenic mice (R. F. Krimm and K. M. Albers, unpublished data), suggesting that an overlapping trophic support mechanism mediated through trkB receptor activation exists for these sensory complexes.

To understand on a mechanistic level how BDNF might elicit the changes found in peripheral innervation, we examined how overexpression in the skin affected full-length and truncated trkB receptor expression in the ganglia. Accumulating evidence has suggested truncated trkB receptors have important roles in mediating physiological effects of BDNF, either by direct signal transduction (Baxter et al., 1997) or as modulators of ligand binding to full-length receptors (Middlemas et al., 1991; Eide et al., 1996). Analyses showed the trkB.T1 form was elevated, albeit modestly, in trigeminal ganglia along with the full-length mRNAs, suggesting the T1 form (more so than the T2 isoform) was recruited in response to the increased levels of peripheral BDNF. This increase in mRNA expression, coupled with the doubling of truncated forms in nerves projecting to the skin, suggests that preferential T1 synthesis and transport occurred in neurons exposed to increased BDNF and that trkB.T1 can modulate BDNF signaling. Because BDNF is released after many types of neuronal injury (Ernfors et al., 1993; Friedman et al., 1995; Wheeler et al., 1998b), understanding the underlying mechanisms and consequence of this response has relevance in design of therapeutic approaches to nerve injury.

\section{REFERENCES}

Acheson A, Lindsay RM (1996) Non target-derived roles of the neurotrophins. Phil Trans R Soc Lond B Biol Sci 351:417-422.

Airaksinen MS, Koltzenburg M, Lewin GR, Masu Y, Helbig C, Wolf E, Brem G, Toyka KV, Thoenen H, Meyer M (1996) Specific subtypes of cutaneous mechanoreceptors require neurotrophin-3 following peripheral target innervation. Neuron 16:287-295.

Albers KM, Wright DE, Davis BM (1994) Overexpression of nerve growth factor in epidermis of transgenic mice causes hypertrophy of the peripheral nervous system. J Neurosci 14:1422-1432.

Albers KM, Perrone TN, Goodness TP, Jones ME, Green MA, Davis B M (1996) Cutaneous overexpression of NT-3 increases sensory and sympathetic neuron number and enhances touch dome and hair follicle innervation. J Cell Biol 134:487-497.

Barbacid M (1994) The Trk family of neurotrophin receptors. J Neurobiol 25:1386-1403.

Baxter GT, Radeke MJ, Kuo RC, Makrides V, Hinkle B, Hoang R, Medina-Selby A, Coit D, Valenzuela P, Feinstein SC (1997) Signal transduction mediated by the truncated trkB receptor isoforms, trkB.T1 and trkB.T2. J Neurosci 17:2683-2690.

Biffo S, Offenhauser N, Carter BD, Barde YA (1995) Selective binding and internalisation by truncated receptors restrict the availability of BDNF during development. Development 121:2461-2470.

Botchkarev VA, Botchkareva NV, Lommatzsch M, Peters EM, Lewin GR, Subramaniam A, Braun A, Renz H, Paus R (1998) BDNF overexpression induces differential increases among subsets of sympathetic innervation in murine back skin. Eur J Neurosci 10:3276-3283.

Buchman VL, Davies AM (1993) Different neurotrophins are expressed and act in a developmental sequence to promote the survival of embryonic sensory neurons. Development 118:989-1001.

Carroll P, Lewin GR, Koltzenburg M, Toyka KV, Thoenen H (1998) A role for BDNF in mechanosensation. Nat Neurosci 1:42-46.

Conover JC, Erickson JT, Katz DM, Bianchi LM, Poueymirou WT, McClain J, Pan L, Helgren M, Ip NY, Boland P, Friedman B, Wiegand S, Vejsada R, Kato AC, DeChiara TM, Yancopoulos GD (1995) Neuronal deficits, not involving motor neurons, in mice lacking BDNF and/or NT4. Nature 375:235-238.

Crowley C, Spencer SD, Nishimura MC, Chen KS, Pitts-Meek S, Armanini MP, Ling LH, McMahon SB, Shelton DL, Levinson AD, Philips HS (1994) Mice lacking nerve growth factor display perinatal loss of sensory and sympathetic neurons yet develop basal forebrain cholinergic neurons. Cell 76:1001-1011.

Davies AM, Bandtlow C, Heumann R, Korsching S, Rohrer H, Thoenen H (1987) Timing and site of nerve growth factor synthesis in developing skin in relation to innervation and expression of the receptor. Nature 326:353-358.

Davis BM, Lewin GR, Mendell LM, Jones ME, Albers KM (1993) Altered expression of nerve growth factor in the skin of transgenic mice leads to changes in response to mechanical stimuli. Neuroscience 56:789-792.

Davis BM, Albers KM, Seroogy KB, Katz DM (1994) Overexpression of nerve growth factor in transgenic mice induces novel sympathetic projections to primary sensory neurons. J Comp Neurol 349:464-474.

Davis BM, Wang HS, Albers KM, Carlson SL, Goodness TP, McKinnon D (1996) Effects of NGF overexpression on anatomical and physiological properties of sympathetic postganglionic neurons. Brain Res 724:47-54.

Davis BM, Fundin BT, Albers KM, Goodness TP, Cronk KM, Rice FL (1997) Overexpression of nerve growth factor in skin causes preferential increases among innervation to specific sensory targets. J Comp Neurol 387:489-506.

Eide FF, Vining ER, Eide BL, Zang K, Wang XY, Reichardt LF (1996) Naturally occurring truncated trkB receptors have dominant inhibitory effects on brain-derived neurotrophic factor signaling. J Neurosci 16:3123-3129.

Erickson JT, Conover JC, Borday V, Champagnat J, Barbacid M, Yancopoulos G, Katz DM (1996) Mice lacking brain-derived neurotrophic factor exhibit visceral sensory neuron losses distinct from mice lacking NT4 and display a severe developmental deficit in control of breathing. J Neurosci 16:5361-5371.

Ernfors P, Wetmore C, Olson L, Persson H (1990) Identification of cells in rat brain and peripheral tissues expressing mRNA for members of the nerve growth factor family. Neuron 5:511-526.

Ernfors P, Rosario CM, Merlio JP, Grant G, Aldskogius H, Persson H (1993) Expression of mRNAs for neurotrophin receptors in the dorsal root ganglion and spinal cord during development and following peripheral or central axotomy. Mol Brain Res 17:217-226.

Ernfors P, Lee KF, Jaenisch R (1994) Mice lacking brain-derived neurotrophic factor develop with sensory deficits. Nature 368:147-150.

Farinas I, Wilkinson GA, Backus C, Reichardt LF, Patapoutian A (1998) Characterization of neurotrophin and Trk receptor functions in developing sensory ganglia: direct NT-3 activation of TrkB neurons in vivo. Neuron 21:325-334.

Friedman B, Kleinfeld D, Ip NY, Verge VM, Moulton R, Boland P, Zlotchenko E, Lindsay RM, Liu L (1995) BDNF and NT-4/5 exert neurotrophic influences on injured adult spinal motor neurons. J Neurosci 15:1044-1056.

Goodness TP, Albers KM, Davis FE, Davis BM (1997) Overexpression of nerve growth factor in skin increases sensory neuron size and modulates Trk receptor expression. Eur J Neurosci 9:1574-1585.

Jones KR, Farinas I, Backus C, Reichardt LF (1994) Targeted disruption of the BDNF gene perturbs brain and sensory neuron development but not motor neuron development. Cell 76:989-999.

Klein R, Conway D, Parada LF, Barbacid M (1990a) The trkB tyrosine protein kinase gene codes for a second neurogenic receptor that lacks the catalytic kinase domain. Cell 61:647-656.

Klein R, Martin-Zanca D, Barbacid M, Parada LF (1990b) Expression of the tyrosine kinase receptor gene trkB is confined to the murine embryonic and adult nervous system. Development 109:845-850.

Liebl DJ, Tessarollo L, Palko ME, Parada LF (1997) Absence of sensory neurons before target innervation in brain-derived neurotrophic factor-, neurotrophin 3-, and TrkC-deficient embryonic mice. J Neurosci 17:9113-9121.

LoPresti P, Scott SA (1994) Target specificity and size of avian sensory neurons supported in vitro by nerve growth factor, brain-derived neurotrophic factor, and neurotrophin-3. J Neurobiol 25:1613-1624.

Maisonpierre PC, Belluscio L, Squinto S, Ip NY, Furth ME, Lindsay RM, Yancopoulos GD (1990) Neurotrophin-3: a neurotrophic factor related to NGF and BDNF. Science 247:1446-1451.

Middlemas DS, Lindberg RA, Hunter T (1991) TrkB, a neural receptor protein-tyrosine kinase: evidence for a full-length and two truncated receptors. Mol Cell Biol 11:143-153.

Mills LR, Nurse CA, Diamond J (1989) The neural dependency of Merkel cell development in the rat: the touch domes and foot pads contrasted. Dev Biol 136:61-74. 
Moll I, Kuhn C, Moll R (1995) Cytokeratin 20 is a general marker of cutaneous Merkel cells while certain neuronal proteins are absent. J Invest Dermatol 104:910-915.

Navarro X, Verdu E, Wendelschafer-Crabb G, Kennedy WR (1995) Innervation of cutaneous structures in the mouse hind paw: a confocal microscopy immunohistochemical study. J Neurosci Res 41:111-120.

Neuhuber WL (1987) Sensory vagal innervation of the rat esophagus and cardia: a light and electron microscopic anterograde tracing study. J Auton Nerv Syst 20:243-255.

Ninkina N, Adu J, Fischer A, Pinon LG, Buchman VL, Davies AM (1996) Expression and function of TrkB variants in developing sensory neurons. EMBO J 15:6385-6393.

Nurse CA, Farraway L (1988) Development of Merkel cell populations with contrasting sensitivities to neonatal deafferentation in the rat whisker pad. Somatosens Mot Res 6:141-162.

Oppenheim RW (1991) Cell death during development of the nervous system. Annu Rev Neurosci 14:453-501.

Paves H, Saarma M (1997) Neurotrophins as in vitro growth cone guidance molecules for embryonic sensory neurons. Cell Tissue Res 290:285-297.

Perl E (1992) Function of dorsal root ganglion neurons: an overview. In: Sensory neurons: diversity, development, and plasticity. (Scott SA, ed), pp 3-23. New York: Oxford UP.

Reichardt LF, Farinas I (1997) Neurotrophic factors and their receptors: roles in neuronal development and function. In: Molecular approaches to neural development. (Cowan MW, Jessell TM, Zipurski L, eds), pp 220-263. New York: Oxford UP.

Rice FL, Albers KM, Davis BM, Silos-Santiago I, Wilkinson GA, LeMaster AM, Ernfors P, Smeyne RJ, Aldskogius H, DeChiara TM, Philips HS, Reichardt LF, Barbacid M, Yancopoulos GD, Fundin BT (1998) Differential dependency of unmyelinated and Ad epidermal and upper dermal innervation on neurotrophins, trk receptors and p75 LNGFR. Dev Biol 198:57-81.

Robinson M, Buj-Bello A, Davies AM (1996) Paracrine interactions of BDNF involving NGF-dependent embryonic sensory neurons. Mol Cell Neurosci 7:143-151.

Rodriguez-Tebar A, Dechant G, Barde YA (1990) Binding of brainderived neurotrophic factor to the nerve growth factor receptor. Neuron 4:487-492.

Rose RD, Rohrlich D (1987) Counting sectioned cells via mathematical reconstruction. J Comp Neurol 263:365-386.
Schecterson LC, Bothwell M (1992) Novel roles for neurotrophins are suggested by BDNF and NT-3 mRNA expression in developing neurons. Neuron 9:449-463.

Silos-Santiago I, Fagan AM, Garber M, Fritzsch B, Barbacid M (1997) Severe sensory deficits but normal CNS development in newborn mice lacking trkB and trkC tyrosine protein kinase receptors. Eur J Neurosci 9:2045-2056.

Siuciak JA, Altar CA, Wiegand SJ, Lindsay RM (1994) Antinociceptive effect of brain-derived neurotrophic factor and neurotrophin-3. Brain Res 633:326-330.

Snider WD (1994) Functions of the neurotrophins during nervous system development: what the knockouts are teaching us. Cell 77:627-638.

Vassar R, Fuchs E (1991) Transgenic mice provide new insights into the role of TGF-a during epidermal development and differentiation. Genes Dev 5:714-727.

Vega JA, Haro JJ, Del Valle ME (1996) Immunohistochemistry of human cutaneous Meissner and pacinian corpuscles. Microsc Res Tech 34:351-361.

Wang X, Zinkel S, Polonsky K, Fuchs E (1997) Transgenic studies with a keratin promoter-driven growth hormone transgene; prospects for gene therapy. Proc Natl Acad Sci USA 94:219-226.

West MJ (1993) New stereological methods for counting neurons. Neurobiol Aging 14:275-285.

Wheeler EF, Gong H, Grimes R, Benoit D, Vazquez L (1998a) p75NTR and Trk receptors are expressed in reciprocal patterns in a wide variety of non-neural tissues during rat embryonic development, indicating independent receptor functions. J Comp Neurol 391:407-428.

Wheeler EF, Naftel JP, Pan M, von Bartheld CS, Byers MR (1998b) Neurotrophin receptor expression is induced in a subpopulation of trigeminal neurons that label by retrograde transport of NGF or fluorogold following tooth injury. Brain Res Mol Brain Res 61:23-38.

Wright EM, Vogel KS, Davies AM (1992) Neurotrophic factors promote the maturation of developing sensory neurons before they become dependent on these factors for survival. Neuron 9:139-150.

Yancopoulos GD, Maisonpierre PC, Ip NY, Aldrich TH, Belluscio L, Boulton TG, Cobb MH, Squinto SP, Furth ME (1990) Neurotrophic factors, their receptors, and the signal transduction pathways they activate. Cold Spring Harbor Symp Quant Biol 55:371-379.

Zhou XF, Rush RA (1996) Endogenous brain-derived neurotrophic factor is anterogradely transported in primary sensory neurons. Neuroscience 74:945-953. 